\title{
The progression of deoxynivalenol-induced growth suppression in nursery pigs and the potential of an algae-modified montmorillonite clay to mitigate these effects ${ }^{1,2}$
}

\author{
H. L. Frobose,* J. A. Erceg,* S. Q. Fowler,* \\ M. D. Tokach,* J. M. DeRouchey,* J. C. Woodworth, * S. S. Dritz, $\dagger$ and R. D. Goodband*3 \\ *Department of Animal Sciences and Industry, College of Agriculture, \\ Kansas State University, Manhattan 66506-0210; and †Department of Diagnostic \\ Medicine/Pathobiology, College of Veterinary Medicine, Kansas State University, Manhattan 66506-0210.
}

\begin{abstract}
Two experiments were conducted to characterize the progression of deoxynivalenol (DON)-induced growth suppression and to investigate algae-modified montmorillonite clay (AMMC) as a means to alleviate the effects of DON in nursery pigs. In both experiments, naturally DON-contaminated wheat was used to produce diets with desired DON levels. In Exp. 1, 280 barrows and gilts $(10.0 \pm 0.2 \mathrm{~kg}$ $\mathrm{BW}$ ) were used in a 28 -d experiment arranged in a $2 \times 2+1$ factorial design with 8 replicates per treatment. The 5 treatments consisted of 2 positive control (PC) diets with DON below detection limits and with or without 0 or $0.50 \%$ AMMC and 3 negative control (NC) diets with $5 \mathrm{mg} / \mathrm{kg}$ of DON and containing $0,0.25$, or $0.50 \%$ AMMC. No DON $\times$ AMMC interactions were observed. Overall, pigs fed DON had decreased $(P<0.001)$ ADG and final BW regardless of AMMC addition. Feeding DON-contaminated diets elicited the most severe depression $(P<0.001)$ in ADFI and G:F from $\mathrm{d} 0$ to 3 , remaining poorer overall $(P<0.01)$ but lessening in severity as exposure time increased. Pigs fed DON diets had greater $(P<0.05)$ within pen $\mathrm{BW}$ variation $(\mathrm{CV})$ on $\mathrm{d} 28$. Although the addition of $0.50 \%$ AMMC to diets restored $(P<0.05)$ ADFI from d 14 to 21 to levels similar to the PC, no
\end{abstract}

other differences were observed for AMMC inclusion. In Exp. 2, 360 barrows (11.4 $\pm 0.2 \mathrm{~kg} \mathrm{BW})$ were used in a 21-d experiment with 9 dietary treatments arranged in a $3 \times 3$ factorial design with DON and AMMC inclusion as main effects. There were 8 replicate pens per treatment. Treatments consisted of 3 PC diets without DON, 3 low-DON (1.5 mg/ $\mathrm{kg}$ DON) $\mathrm{NC}$ diets, and 3 high-DON ( $3 \mathrm{mg} / \mathrm{kg}$ DON) NC diets with $0,0.17$, or $0.50 \%$ AMMC incorporated at each DON level. No DON $\times$ AMMC interactions were observed. As DON level increased, ADG and final BW decreased (quadratic, $P<0.05$ ), driven by decreased (quadratic, $P<0.01$ ) ADFI and poorer (quadratic; $P<$ $0.05) \mathrm{G}: \mathrm{F}$. At both 1.5 and $3 \mathrm{mg} / \mathrm{kg}$ DON, reductions in ADG were most marked from d 0 to 7 (15 to $22 \%$ lower) and were least distinct from d 14 to 21 (5 to $6 \%$ lower). Incorporating AMMC at increasing levels had no effect on ADG, ADFI, G:F, or final BW. Overall, these experiments reinforce DON effects on feed intake but also indicate that the effects of DON on G:F may be more severe than previously thought. Furthermore, some pigs appear to develop tolerance to DON, as effects on ADFI and G:F lessen over time. However, the addition of AMMC did not offset the deleterious effects of DON.

Key words: deoxynivalenol, detoxifying agents, montmorillonite clay, nursery pig, swine, vomitoxin

(C) 2016 American Society of Animal Science. All rights reserved.

\footnotetext{
${ }^{1}$ Contribution no. 16-359-J from the Kansas Agricultural Experiment Station, Manhattan, KS 66506-0210.

${ }^{2}$ Appreciation is expressed to Olmix North America (Black River Falls, WI) for supplying the deoxynivalenol-contaminated wheat and for partial financial support of the study.

${ }^{3}$ Corresponding author: Goodband@ksu.edu

Received May 23, 2016.

Accepted June 9, 2016.
}

J. Anim. Sci. 2016.94:3746-3759 doi: $10.2527 /$ jas2016-0663

\section{INTRODUCTION}

Deoxynivalenol (DON) is a member of the type B trichothecenes, which are potent inhibitors of protein synthesis (Rotter et al., 1996). Primarily produced by Fusarium fungi, trichothecenes proliferate in cereal grains when flowering coincides with temperate, wet conditions (CAST, 2003). According to a global 
survey, DON is the most common mycotoxin in North American feedstuffs, present in $75 \%$ of samples at an average of $1.3 \mathrm{mg} / \mathrm{kg}$ (Rodrigues and Naehrer, 2012).

Among farm animals, pigs are the most sensitive to DON (Eriksen and Petterson, 2004). While vomiting occurs at high concentrations (Forsyth et al., 1977; Pestka et al., 1987), most reports agree that realistic DON levels (1 to $5 \mathrm{mg} / \mathrm{kg}$ ) primarily decrease feed intake (Friend et al., 1984; Patience et al., 2014). Deoxynivalenol also reduces intestinal absorption (Grenier and Applegate, 2013) and stimulates and suppresses the immune system (Rotter et al., 1996; Pestka et al., 2004). The severity seems to be dose-dependent, and fluctuations may be related to contradictory feed efficiency effects (Etienne and Waché, 2008). Some reports have observed DON effects lessening over time (Friend et al., 1984; Pollman et al., 1985), but this phenomenon is not well-characterized.

Since environmental conditions dictate DON growth, various methods have been tested to detoxify DON prior to feeding, and feed additives appear to be the most practical (Dänicke, 2002; Awad et al., 2010). Clay minerals used successfully against polar toxins, such as aflatoxins, have poor DON adsorption (Ramos et al., 1996; EFSA, 2009). However, an algae-modified montmorillonite clay (AMMC; Olmix S.A., Brehan, France) has been developed using algal polysaccharides, which enhance the DON adsorptive capacity (Havenaar and Demais, 2006). Therefore, the objectives of the present research were to further characterize the progression of DON-induced suppression of growth and to investigate AMMC as a means to alleviate the effects of DON in nursery pigs.

\section{MATERIALS AND METHODS}

All experimental procedures and animal care were approved by the Kansas State Institutional Animal Care and Use Committee. In both experiments, diets were corn-soybean meal based, and sources of both low-DON and naturally DON-contaminated hard red winter wheat were provided by Olmix N.A. (Black River Falls, WI). To maintain consistency and ensure that diets contained the desired levels of DON, basal ingredients (corn and the 2 wheat sources) were analyzed for mycotoxin concentration at North Dakota State University Veterinary Diagnostic Laboratory (NDSU; Fargo, ND) prior to diet formulation and incorporated into test diets to achieve desired DON concentrations. At the manufacturer's request, the DON-contaminated wheat was also analyzed for mycotoxin content at LABOCEA (Ploufragan, France). Due to concerns that high-DON wheat may also have a different AA profile than low-DON wheat, both were analyzed for AA content at the University of Missouri Agricultural Experiment Station Chemical Laboratories (Columbia, $\mathrm{MO}$ ), and diet formulation was adjusted to account for the differences. Diets were formulated to meet or exceed all nutrient requirement estimates (NRC, 2012). As recommended by Döll and Dänicke (2003), to evaluate both the specific and unspecific effects of the AMMC feed additive, factorial designs were used in both experiments. The AMMC product is made up primarily of montmorillonite and 10 to $20 \%$ algae. According to a chemical analysis conducted at Dairyland Laboratories (St. Cloud, $\mathrm{MN}$ ), AMMC contained $6.27 \% \mathrm{CP}, 4.5 \%$ sugar, $4.3 \% \mathrm{Ca}$, $0.94 \% \mathrm{Na}, 0.90 \% \mathrm{Cl}, 0.17 \% \mathrm{P}$, and $1.06 \% \mathrm{~K}$.

\section{Experiment 1}

A total of 280 barrows and gilts (PIC $327 \times 1050$; Hendersonville, $\mathrm{TN}$ ) were used in a 28 -d experiment to determine the effects of DON and AMMC on nursery pig growth. Pigs were initially $10.0 \pm 0.2 \mathrm{~kg} \mathrm{BW}$ and $35 \mathrm{~d}$ of age, and there were 8 replicate pens per treatment with 7 pigs in each pen. At weaning, pigs were allotted to pens by initial BW, individual variation in BW, and gender. Pigs were fed a common commercial starter diet for $7 \mathrm{~d}$, at which time they were reweighed and pens were assigned to 1 of 5 treatments in a completely randomized design.

Treatments were arranged in a $2 \times 2+1$ factorial with DON and AMMC inclusion as main effects. Treatments consisted of 2 positive control diets (PC; < $0.5 \mathrm{mg} / \mathrm{kg} \mathrm{DON})$, containing either 0 or $0.50 \% \mathrm{AMMC}$, and 3 negative control diets (NC), formulated to contain $5 \mathrm{mg} / \mathrm{kg}$ DON and either $0,0.25$, or $0.50 \%$ AMMC. Apart from the inclusion of DON and AMMC, diets were formulated to be identical in nutrient composition.

Diets were manufactured at the Kansas State University Grain Science Feed Mill. While the stability of AMMC under pelleting conditions is unknown, due to concerns of ingredient segregation, diets were pelleted. A naturally contaminated source of high-DON wheat $(10.7 \mathrm{mg} / \mathrm{kg} \mathrm{DON})$ was used to provide diets with $5 \mathrm{mg} / \mathrm{kg}$ DON. Following final diet manufacturing, diet samples were sent to NDSU for mycotoxin analysis. Only mycotoxins detected above quantitative limits in at least 1 of the experimental diets were reported. Final diets were also sent to the University of Missouri for nutrient analysis.

The trial was conducted at the K-State Swine Teaching and Research Center in Manhattan, KS Each pen $(1.22$ by $1.52 \mathrm{~m})$ contained a 4-hole, dry self-feeder and a nipple waterer to provide ad libitum access to feed and water. Pigs were examined daily, and feeders were adjusted to maintain approximately $50 \%$ pan coverage. Average daily gain, ADFI, and feed efficiency were determined by weighing pigs and measuring feed disappearance on $\mathrm{d} 0,3,7,14,21$, and 28. Since pens were initially balanced for within-pen 
weight variation, pen $\mathrm{CV}$ was also calculated at $\mathrm{d} 28$ to evaluate the effect of DON on pig BW variation.

\section{Experiment 2}

A total of 360 barrows (Line 1050; PIC; initially $11.4 \pm 0.2 \mathrm{~kg}$ and $45 \mathrm{~d}$ of age) were used in a 21-d experiment to further characterize the effects of DON and AMMC on nursery pig growth. Pigs were shipped to the facility immediately postweaning and were placed in 2 identical nurseries, each containing 40 pens. Upon arrival, pigs were allotted to pens by BW and fed a common commercial diet for the first 24 d. After pigs reached approximately $12 \mathrm{~kg}$, pens were randomly assigned to 1 of 9 dietary treatments. There were 5 pigs per pen and 8 replicate pens per treatment.

Dietary treatments were arranged in a $3 \times 3$ factorial design with DON and AMMC inclusion as the main effects. Treatments consisted of 3 PC diets without DON, 3 low-NC (1.5 mg/kg DON) diets, and 3 high-NC (3 mg/kg DON) diets with $0,0.17$, or $0.50 \%$ AMMC incorporated at each level of DON. Diets were manufactured in meal form at the Kansas State University O. H. Kruse Feed Mill in Manhattan, KS.

The $0.17 \%$ AMMC inclusion rate was chosen to reflect the manufacturer-recommended feeding level, and the $0.50 \%$ inclusion was added to test the ingredient at concentrations known to be effective when similar absorptive clays are added to aflatoxin-contaminated grains (Schell et al., 1993). The AMMC was added at the expense of corn in the diet formulation. Diets exceeded NRC (2012) nutrient requirements, and apart from the inclusion of DON and AMMC, were formulated to be identical in nutrient composition.

Because of a concern that pelleting may have impacted the efficacy of AMMC in Exp. 1, diets were manufactured in meal form at the Kansas State University O. H. Kruse Feed Mill in Manhattan, KS in Exp. 2. A naturally contaminated source of highDON wheat $(6.0 \mathrm{mg} / \mathrm{kg}$ DON) was used to provide diets with the desired DON concentrations. Following final diet manufacturing, diet samples were sent to NDSU for mycotoxin analysis. Only mycotoxins detected above quantitative limits in at least 1 of the experimental diets were reported. Final diets were also sent to the University of Missouri for nutrient analysis.

This experiment was conducted at the Kansas State University Segregated Early Weaning Research Facility in Manhattan, KS. Each pen (1.22 by 1.22 m) contained a 4-hole dry self-feeder and a 1-cup waterer to provide ad libitum access to feed and water. Pigs were examined daily, and feeders were adjusted to maintain approximately $50 \%$ pan coverage. Average daily gain, ADFI, and G:F were determined
Table 1. Amino acid analysis of hard red winter wheat source, Exp. 1 and 2 (as-fed basis) ${ }^{1}$

\begin{tabular}{lcccc}
\hline \hline & \multicolumn{2}{c}{ Exp. 1 } & \multicolumn{2}{c}{ Exp. 2 } \\
\cline { 2 - 5 } Item, \% & Low DON & High DON & Low DON & High DON \\
\hline Moisture & 9.47 & 9.83 & 9.14 & 10.19 \\
CP & 12.86 & 10.16 & 11.80 & 12.20 \\
AA analysis & & & & \\
$\quad$ Lys & 0.40 & 0.37 & 0.40 & 0.44 \\
Ile & 0.47 & 0.36 & 0.41 & 0.47 \\
Leu & 0.91 & 0.72 & 0.84 & 0.87 \\
Met & 0.21 & 0.16 & 0.21 & 0.22 \\
Cys & 0.28 & 0.22 & 0.27 & 0.27 \\
Thr & 0.37 & 0.30 & 0.36 & 0.38 \\
Trp & 0.18 & 0.12 & 0.15 & 0.17 \\
Val & 0.62 & 0.50 & 0.57 & 0.47 \\
\hline
\end{tabular}

${ }^{1}$ Samples were analyzed for AA profile at the University of Missouri Experiment Station Chemical Laboratories in Columbia, MO.

${ }^{2} \mathrm{DON}=$ deoxynivalenol.

by weighing pigs and measuring feed disappearance on d $0,3,7,14$, and 21 .

\section{Mycotoxin Analysis}

In both experiments, samples of the basal ingredients (corn and 2 wheat sources) and final diets were sent to NDSU for an 18-component mycotoxin analysis. The analysis for trichothecene mycotoxins (DON, 15-acetyldeoxynivalenol, 3-acetyldeoxynivalenol, nivalenol, and $\mathrm{T}-2$ toxin) along with zearalenone and zearalenol was conducted according to a modified version of Groves et al. (1999) using gas chromatography coupled with mass spectrometry. Aflatoxins and fumonisins were analyzed by HPLC. Samples were tested on an as-fed basis, and the practical quantitation limit for trichothecenes was $0.50 \mathrm{mg} / \mathrm{kg}$ while the detection limits were $2.0 \mathrm{mg} / \mathrm{kg}$ for fumonisins and $20 \mu \mathrm{g} / \mathrm{kg}$ for aflatoxins. In both studies, the high-DON wheat was also sent to LABOCEA where a 43-component toxin screen was performed using liquid chromatography coupled with tandem mass spectrometry techniques. For all toxins, the minimum detection limit at LABOCEA was $10 \mu \mathrm{g} / \mathrm{kg}$ feed.

\section{Statistical Analysis}

For both experiments, results were analyzed as a completely randomized design using the MIXED procedure of SAS (SAS Inst., Inc., Cary, NC). The fixed factors in the models included DON level and AMMC inclusion. For Exp. 1, differences were evaluated using pre-planned contrasts, which included 1) the 2-way interaction evaluating the effect of AMMC inclusion at $0.50 \%$ compared to none in the PC and NC diets, 2) pigs fed PC vs. NC diets regardless of AMMC inclu- 
Table 2. Formulated diet composition, Exp. 1 (as-fed basis)

\begin{tabular}{|c|c|c|c|c|c|}
\hline \multirow[b]{2}{*}{ Item $\mathrm{AMMC}^{2}$ : } & \multicolumn{2}{|c|}{ Positive control $\left(<0.5 \mathrm{mg} / \mathrm{kg} \mathrm{DON}^{1}\right)$} & \multicolumn{3}{|c|}{ Negative control $(5.0 \mathrm{mg} / \mathrm{kg}$ DON$)$} \\
\hline & None & $0.50 \%$ & None & $0.25 \%$ & $0.50 \%$ \\
\hline$\overline{\text { Corn }}$ & 16.90 & 16.40 & 16.33 & 16.20 & 15.88 \\
\hline Soybean meal, $46.5 \% \mathrm{CP}$ & 30.93 & 30.98 & 31.45 & 31.35 & 31.45 \\
\hline Hard red winter (HRW) wheat & 46.75 & 46.75 & & & \\
\hline High-DON ${ }^{3}$ HRW wheat & & & 46.75 & 46.75 & 46.75 \\
\hline Soybean oil & 2.00 & 2.00 & 2.00 & 2.00 & 2.00 \\
\hline Monocalcium phosphate, $21 \% \mathrm{P}$ & 1.05 & 1.05 & 1.05 & 1.05 & 1.05 \\
\hline Limestone & 1.05 & 1.00 & 1.05 & 1.03 & 1.00 \\
\hline Salt & 0.35 & 0.35 & 0.35 & 0.35 & 0.35 \\
\hline Vitamin premix with phytase $e^{4,5}$ & 0.25 & 0.25 & 0.25 & 0.25 & 0.25 \\
\hline Trace mineral premix 6 & 0.15 & 0.15 & 0.15 & 0.15 & 0.15 \\
\hline L-Lys HCl & 0.33 & 0.33 & 0.33 & 0.33 & 0.33 \\
\hline DL-Met & 0.10 & 0.10 & 0.15 & 0.15 & 0.15 \\
\hline L-Thr & 0.14 & 0.14 & 0.14 & 0.14 & 0.14 \\
\hline AMMC & & 0.50 & & 0.25 & 0.50 \\
\hline Total & 100 & 100 & 100 & 100 & 100 \\
\hline \multicolumn{6}{|l|}{ Calculated analysis } \\
\hline \multicolumn{6}{|l|}{$\mathrm{SID}^{7} \mathrm{AA}, \%$} \\
\hline Lys & 1.28 & 1.28 & 1.28 & 1.28 & 1.28 \\
\hline Ile:Lys & 65 & 65 & 62 & 62 & 62 \\
\hline Leu:Lys & 120 & 120 & 115 & 115 & 115 \\
\hline Met:Lys & 31 & 31 & 33 & 33 & 33 \\
\hline Met and Cys:Lys & 58 & 58 & 58 & 58 & 58 \\
\hline Thr:Lys & 64 & 64 & 64 & 64 & 64 \\
\hline Trp:Lys & 20.7 & 20.7 & 18.9 & 18.9 & 18.9 \\
\hline Val:Lys & 72 & 72 & 69 & 69 & 69 \\
\hline Total Lys, \% & 1.42 & 1.42 & 1.42 & 1.42 & 1.42 \\
\hline ME, $\mathrm{kcal} / \mathrm{kg}$ & 3318 & 3303 & 3318 & 3309 & 3303 \\
\hline SID Lys:ME, g/Mcal & 3.86 & 3.89 & 3.87 & 3.87 & 3.89 \\
\hline $\mathrm{CP}, \%$ & 22.3 & 22.3 & 21.2 & 21.2 & 21.3 \\
\hline $\mathrm{Ca}, \%$ & 0.73 & 0.73 & 0.73 & 0.73 & 0.74 \\
\hline $\mathrm{P}, \%$ & 0.65 & 0.65 & 0.66 & 0.66 & 0.66 \\
\hline Available P, \% & 0.48 & 0.48 & 0.49 & 0.48 & 0.48 \\
\hline
\end{tabular}

${ }^{1} \mathrm{DON}=$ deoxynivalenol.

${ }^{2} \mathrm{AMMC}=$ algae-modified montmorillonite clay product (Olmix S.A., Brehan, France).

${ }^{3}$ Analyzed DON concentration in HRW wheat was $10.7 \mathrm{mg} / \mathrm{kg}$.

${ }^{4}$ Provided per kilogram of premix: 4,409,200 IU vitamin A; 551,150 IU vitamin $\mathrm{D}_{3}$; 17,637 IU vitamin E; 1,764 mg vitamin K; 3,307 mg riboflavin; $11,023 \mathrm{mg}$ pantothenic acid; $19,841 \mathrm{mg}$ niacin; and $15.4 \mathrm{mg}$ vitamin $\mathrm{B}_{12}$.

${ }^{5}$ Phyzyme 600 (Danisco Animal Nutrition, St. Louis, MO) provided 750 phytase units phytase $/ \mathrm{kg}$ of diet and $0.13 \%$ available P released.

${ }^{6}$ Provided per kilogram of premix: $22.0 \mathrm{~g} \mathrm{Mn}$ from manganese oxide, $73.4 \mathrm{~g}$ Fe from iron sulfate, $73.4 \mathrm{~g} \mathrm{Zn}$ from zinc sulfate, $11.0 \mathrm{~g}$ Cu from copper sulfate, $198 \mathrm{mg}$ I from calcium iodate, and $198 \mathrm{mg}$ Se from sodium selenite.

${ }^{7} \mathrm{SID}=$ standardized ileal digestible.

sion, 3$)$ the addition of AMMC ( 0 vs. $0.50 \%)$ in both $\mathrm{PC}$ and $\mathrm{NC}$ diets, and 4) the linear effects of AMMC inclusion within $\mathrm{NC}$ diets alone.

In Exp. 2, the main effects of DON level $(0,1.5$, or $3.0 \mathrm{mg} / \mathrm{kg}$ ) and AMMC inclusion $(0,0.17$, or $0.50 \%)$ and their 2-way interactions served as fixed effects and barn as a random effect in the model. Preplanned linear and quadratic orthogonal contrasts were used to evalu- ate the effect of dose. The coefficients for the unequally spaced linear and quadratic contrasts were derived using the IML procedure in SAS. In both experiments, pen was used as the experimental unit, and least squares means were calculated for each independent variable.

Differences were considered significant at $P$ values of $\leq 0.05$ and marginally significant at $P$ values of $>0.05$ and $\leq 0.10$. 
Table 3. Nutrient analysis of experimental diets, Exp. 1 (as-fed basis) ${ }^{1}$

\begin{tabular}{lrrrrrr}
\hline \hline & \multicolumn{2}{c}{$\begin{array}{c}\text { Positive control } \\
\left(<0.5 \mathrm{mg} / \mathrm{kg} \mathrm{DON}^{2}\right)\end{array}$} & & \multicolumn{3}{c}{$\begin{array}{c}\text { Negative control } \\
(5.0 \mathrm{mg} / \mathrm{kg} \text { DON })\end{array}$} \\
\cline { 2 - 3 } \cline { 5 - 7 } Item, \% & None & $0.50 \%$ & & None & $0.25 \%$ & $0.50 \%$ \\
\hline MMMC ${ }^{3}:$ & 10.88 & 10.80 & & 10.74 & 10.63 & 10.76 \\
Moisture & 23.00 & 23.26 & & 22.29 & 22.04 & 22.51 \\
Ether extract & 3.16 & 3.22 & & 2.93 & 3.08 & 3.02 \\
Ash & 5.03 & 5.41 & 5.68 & 5.82 & 5.82 \\
AA analysis & & & & & \\
$\quad$ Lys & 1.41 & 1.42 & 1.41 & 1.41 & 1.49 \\
Ile & 0.87 & 0.90 & 0.85 & 0.84 & 0.91 \\
Leu & 1.71 & 1.71 & 1.66 & 1.60 & 1.67 \\
Met & 0.43 & 0.41 & 0.45 & 0.41 & 0.49 \\
Cys & 0.38 & 0.36 & 0.35 & 0.32 & 0.36 \\
Thr & 0.90 & 0.90 & 0.84 & 0.86 & 0.89 \\
Trp & 0.30 & 0.29 & 0.28 & 0.30 & 0.30 \\
Val & 0.99 & 1.01 & 0.96 & 0.95 & 1.02 \\
\hline
\end{tabular}

${ }^{1}$ Samples were analyzed at the University of Missouri Agricultural Experiment Station Chemical Laboratories in Columbia, MO.

${ }^{2} \mathrm{DON}=$ deoxynivalenol.

${ }^{3} \mathrm{AMMC}=$ algae-modified montmorillonite clay (Olmix S. A., Brehan, France).

\section{RESULTS}

\section{Experiment 1}

The AA concentrations (Table 1) of low-DON wheat were generally greater than those of the DONcontaminated wheat, and differences were accounted for in diet formulation (Table 2). Nutrient analyses of experimental diets were consistent with formulated levels, and increased analyzed ash content in AMMC diets correspond with the presence of additional clay (Table 3 ). Given the analyzed DON concentrations of the low- and high-DON wheat (Table 4), the analyzed DON concentrations of the PC diets accurately reflected formulated levels of $<0.5 \mathrm{mg} / \mathrm{kg}$, whereas the $\mathrm{NC}$ diets averaged 6.6 $\mathrm{mg} / \mathrm{kg}$ DON (range 6.4 to $6.7 \mathrm{mg} / \mathrm{kg}$ ), approximately $20 \%$ greater than formulated (Table 5). Although fumonisin $\mathrm{B}_{1}$ was detected at $2.0 \mathrm{mg} / \mathrm{kg}$ in the $\mathrm{NC}$ diet without AMMC, analyses confirmed that no other mycotoxins were detected in PC diets above detection limits. Aflatoxin B1 was detected at low levels ( 20 and $28 \mu \mathrm{g} / \mathrm{kg}$ ) in 2 of $3 \mathrm{NC}$ diets, but no other mycotoxins were detected in $\mathrm{NC}$ diets.

For pig growth performance (Table 6), a 2-way $\mathrm{DON} \times \mathrm{AMMC}$ interaction was detected from $\mathrm{d} 4$ to 7, where the addition of AMMC improved $(P<0.05)$ ADG and G:F in NC diets but worsened ADG and G:F in PC diets. No other interactions were detected within period or overall, nor were any linear effects detected for increasing the inclusion rate of AMMC.

From $\mathrm{d} 0$ to 3, pigs fed NC diets had decreased $(P<$ 0.001) ADG, ADFI, and feed efficiency compared to
Table 4. Mycotoxin analysis of basal ingredients, Exp. 1 (as-fed basis)

\begin{tabular}{|c|c|c|c|}
\hline \multirow[b]{2}{*}{ Item, $\mathrm{mg} / \mathrm{kg}$} & \multirow[b]{2}{*}{ Ground corn } & \multicolumn{2}{|c|}{ Hard red winter wheat } \\
\hline & & Low DON $^{1}$ & High DON \\
\hline \multicolumn{4}{|l|}{$\overline{\mathrm{NDSU}^{2}}$} \\
\hline DON & $<0.50$ & $<0.50$ & $10.60^{3}$ \\
\hline \multicolumn{4}{|l|}{ LABOCEA $^{4}$} \\
\hline DON & $\mathrm{NT}^{5}$ & NT & 10.70 \\
\hline 15-Acetyl DON & NT & NT & 0.12 \\
\hline Zearalenone & NT & NT & 0.35 \\
\hline Fumonisin $\mathrm{B}_{1}$ & NT & NT & 0.03 \\
\hline \multicolumn{4}{|c|}{${ }^{1} \mathrm{DON}=$ deoxynivalenol. } \\
\hline \multicolumn{4}{|c|}{$\begin{array}{l}\text { Laboratory, Fargo, ND. Samples were sent for an } 18 \text {-component myco- } \\
\text { toxin analysis and were analyzed using a variety of mass spectrometry, } \\
\text { ELISA, and HPLC methods. Included in the table are mycotoxins found at } \\
\text { levels above detection limits }(0.5 \mathrm{mg} / \mathrm{kg}) \text {. }\end{array}$} \\
\hline \multicolumn{4}{|c|}{$\begin{array}{l}{ }^{3} \text { Mean of two duplicate samples sent to NDSU. Individual samples had } \\
\text { DON levels of } 10.0 \text { and } 11.1 \mathrm{mg} / \mathrm{kg} \text {, respectively. }\end{array}$} \\
\hline \multicolumn{4}{|c|}{$\begin{array}{l}{ }^{4} \text { LABOCEA, Ploufragan, France. Samples were analyzed using a } \\
43 \text {-component toxin screen using liquid-chromatography coupled with } \\
\text { tandem mass spectrometry analysis techniques. Included in the table are } \\
\text { mycotoxins found at levels above detection limits }(10 \mu \mathrm{g} / \mathrm{kg}) \text {. }\end{array}$} \\
\hline
\end{tabular}

pigs fed PC diets. The addition of AMMC to diets had no effect on pig growth. A similar pattern of growth was observed from d 4 to 7, with pigs fed NC diets having decreased $(P<0.05)$ ADG, ADFI, and G:F compared to $\mathrm{PC}$ diets, and no differences in growth were detected for AMMC inclusion. From d 7 to 14, pigs fed NC diets continued to have decreased $(P<0.001)$ ADG driven by reduced $(P<0.05)$ feed intake, but no effect of feed efficiency was observed during this period. Once again, the addition of AMMC did not impact pig performance.

From d 14 to 21, ADG and ADFI were decreased $(P<0.05)$ for pigs fed NC diets, but feed efficiency was not affected. The addition of AMMC increased $(P<0.05)$ feed intake, but no effects on ADG or G:F were observed. During the final period (d 21 to 28),

Table 5. Mycotoxin analysis of experimental diets, Exp. 1 (as-fed basis) ${ }^{1}$

\begin{tabular}{|c|c|c|c|c|c|}
\hline \multirow[b]{2}{*}{ Item $\mathrm{AMMC}^{3}$ : } & \multicolumn{2}{|c|}{$\begin{array}{c}\text { Positive control } \\
\left(<0.5 \mathrm{mg} / \mathrm{kg} \mathrm{DON}^{2}\right)\end{array}$} & \multicolumn{3}{|c|}{$\begin{array}{l}\text { Negative control } \\
(5.0 \mathrm{mg} / \mathrm{kg} \text { DON })\end{array}$} \\
\hline & None & $0.50 \%$ & None & $0.25 \%$ & $0.50 \%$ \\
\hline$\overline{\mathrm{DON}^{2}, \mathrm{mg} / \mathrm{kg}}$ & $<0.5$ & $<0.5$ & 6.6 & 6.7 & 6.4 \\
\hline Fumonisin $\mathrm{B}_{1} \mathrm{mg} / \mathrm{kg}$ & 2.0 & $<2.0$ & $<2.0$ & $<2.0$ & $<2.0$ \\
\hline Aflatoxin $\mathrm{B}_{1}, \mu \mathrm{g} / \mathrm{kg}$ & $<20$ & $<20$ & 20 & 28 & $<20$ \\
\hline
\end{tabular}

${ }^{1}$ North Dakota State University Veterinary Diagnostic Laboratory, Fargo, ND. Samples were sent for 18-component mycotoxin analysis and analyzed using a variety of mass spectrometry, ELISA, and HPLC methods. Included in the table are mycotoxins found at levels above detection limits in at least one diet.

${ }^{2} \mathrm{DON}=$ deoxynivalenol.

${ }^{3} \mathrm{AMMC}=$ algae-modified montmorillonite clay (Olmix S.A., Brehan, France). 
Table 6. Effects of deoxynivalenol (DON) and an algae-modified montmorillonite clay (AMMC; Olmix S.A., Brehan, France) on nursery pig performance, Exp. $1^{1}$

\begin{tabular}{|c|c|c|c|c|c|c|c|c|}
\hline \multirow[b]{2}{*}{ Item AMMC: } & \multicolumn{2}{|c|}{ Positive control $(<0.5 \mathrm{mg} / \mathrm{kg} \mathrm{DON})^{2}$} & \multicolumn{3}{|c|}{ Negative control $(5.0 \mathrm{mg} / \mathrm{kg} \mathrm{DON})^{3}$} & \multirow[b]{2}{*}{ SEM } & \multicolumn{2}{|c|}{ Probability ${ }^{4,5}, P<$} \\
\hline & None & $0.50 \%$ & None & $0.25 \%$ & $0.50 \%$ & & $\mathrm{DON}$ & AMMC \\
\hline \multicolumn{9}{|l|}{ d 0 to 3} \\
\hline ADG, $g$ & 178 & 233 & 20 & 24 & -1 & 45.4 & 0.001 & 0.511 \\
\hline ADFI, $g$ & 410 & 398 & 302 & 315 & 293 & 59.0 & 0.001 & 0.677 \\
\hline G:F & 0.396 & 0.558 & 0.038 & 0.075 & 0.012 & 0.109 & 0.001 & 0.369 \\
\hline \multicolumn{9}{|l|}{ d 4 to 7} \\
\hline ADG, $g$ & 411 & 340 & 233 & 262 & 261 & 21.3 & 0.001 & 0.141 \\
\hline ADFI, $g$ & 497 & 485 & 415 & 436 & 412 & 85.0 & 0.042 & 0.838 \\
\hline G:F & 0.832 & 0.702 & 0.596 & 0.646 & 0.660 & 0.083 & 0.001 & 0.362 \\
\hline \multicolumn{9}{|l|}{ d 7 to 14} \\
\hline $\mathrm{ADG}, \mathrm{g}$ & 526 & 530 & 418 & 396 & 458 & 17.5 & 0.001 & 0.178 \\
\hline ADFI, g & 704 & 735 & 558 & 583 & 611 & 44.6 & 0.001 & 0.161 \\
\hline G:F & 0.747 & 0.718 & 0.743 & 0.686 & 0.751 & 0.032 & 0.571 & 0.690 \\
\hline \multicolumn{9}{|l|}{ d 14 to 21} \\
\hline $\mathrm{ADG}, \mathrm{g}$ & 527 & 586 & 476 & 462 & 483 & 32.2 & 0.001 & 0.138 \\
\hline ADFI, g & 814 & 858 & 728 & 734 & 814 & 37.3 & 0.025 & 0.024 \\
\hline G:F & 0.652 & 0.688 & 0.660 & 0.634 & 0.603 & 0.024 & 0.113 & 0.674 \\
\hline \multicolumn{9}{|l|}{ d 21 to 28} \\
\hline ADG, $g$ & 676 & 633 & 579 & 537 & 559 & 35.5 & 0.023 & 0.383 \\
\hline ADFI, g & 1,035 & 1,022 & 934 & 907 & 1018 & 36.8 & 0.166 & 0.348 \\
\hline $\mathrm{G}: \mathrm{F}$ & 0.656 & 0.618 & 0.622 & 0.590 & 0.554 & 0.033 & 0.156 & 0.124 \\
\hline \multicolumn{9}{|l|}{ d 0 to 28} \\
\hline ADG, $g$ & 533 & 516 & 420 & 403 & 421 & 14.2 & 0.001 & 0.581 \\
\hline ADFI, $g$ & 782 & 784 & 686 & 693 & 726 & 23.2 & 0.003 & 0.364 \\
\hline G:F & 0.683 & 0.658 & 0.614 & 0.585 & 0.583 & 0.021 & 0.002 & 0.201 \\
\hline \multicolumn{9}{|l|}{ Pig BW, kg } \\
\hline $\mathrm{d} 0$ & 10.2 & 10.0 & 9.90 & 10.0 & 10.0 & 0.09 & 0.251 & 0.332 \\
\hline $\mathrm{d} 28$ & 24.9 & 24.4 & 21.7 & 21.4 & 21.8 & 0.41 & 0.001 & 0.632 \\
\hline \multicolumn{9}{|l|}{ Pen $\mathrm{CV}, \%$} \\
\hline $\mathrm{d} 0$ & 14.1 & 13.8 & 14.2 & 14.4 & 14.7 & 1.00 & 0.226 & 0.763 \\
\hline d 28 & 13.6 & 12.4 & 17.1 & 16.4 & 14.8 & 0.015 & 0.051 & 0.249 \\
\hline
\end{tabular}

${ }^{1} \mathrm{~A}$ total of 280 barrows and gilts (PIC $327 \times 1050 ; 35 \mathrm{~d}$ of age) were used in this 28 -d study, with 7 pigs per pen and 8 pens per treatment.

${ }^{2}$ Formulated levels. A high-DON wheat source was used to produce diets with $5 \mathrm{mg} / \mathrm{kg}$ DON.

${ }^{3}$ Analyzed DON averaged $<0.5$ and $6.6 \mathrm{mg} / \mathrm{kg}$ for positive and negative control diets, respectively.

${ }^{4}$ A 2-way DON $\times$ AMMC interaction was detected $(P<0.01)$ from d 4 to 7 where the addition of AMMC improved ADG and G:F in negative control diets, but worsened ADG and G:F in positive control diets. No other interactions were detected within period or overall.

${ }^{5}$ No linear effects $(P>0.05)$ due to AMMC inclusion within DON-contaminated diets were found. AMMC contrast compares diets without AMMC to those containing AMMC at $0.50 \%$.

pigs fed NC diets had decreased $(P<0.05)$ ADG, but no other treatment effects were seen.

Overall ( 0 to 28), pigs fed the NC diets had reduced ADG $(P<0.001)$, driven by poorer $(P<0.01)$ ADFI and G:F, which resulted in decreased $(P<0.001)$ final BW compared to PC-fed pigs. However, the addition of AMMC had no effect. Coefficient of variation of pig BW within pen tended $(P=0.051)$ to be greater in pigs fed NC diets vs. those fed the PC diets.

\section{Experiment 2}

Since CP and AA levels were marginally but consistently greater in the DON-contaminated wheat (Table 1), the soybean meal fraction was increased slightly in PC diets to reflect this difference (Table 7). In the experimental diets, proximate analyses were generally in line with formulated values, and the addition of AMMC was reflected by greater ash contents in those diets (Table 8). Analyzed DON concentrations (Table 9) in the natu ally DON-contaminated wheat differed between NDSU $(8.4 \mathrm{mg} / \mathrm{kg})$ and LABOCEA $(6.0 \mathrm{mg} / \mathrm{kg})$. Low levels of several other mycotoxins were detected in the DONcontaminated wheat source. To ensure that final diet DON levels were adequate to achieve a DON-associated reduction in performance, the analysis from LABOCEA was used as the basis for diet formulation. Analyzed DON in the final diets revealed levels that were within $20 \%$ of 
Table 7. Formulated diet composition, Exp. 2 (as-fed basis)

\begin{tabular}{|c|c|c|c|c|c|c|c|c|c|}
\hline \multirow[b]{2}{*}{ Item $\mathrm{AMMC}^{2}$ : } & \multicolumn{3}{|c|}{$\begin{array}{c}\text { Positive control } \\
\left(<0.5 \mathrm{mg} / \mathrm{kg} \mathrm{DON}^{1}\right)\end{array}$} & \multicolumn{3}{|c|}{$\begin{array}{l}\text { Low negative control } \\
(1.5 \mathrm{mg} / \mathrm{kg} \text { DON })\end{array}$} & \multicolumn{3}{|c|}{$\begin{array}{l}\text { High negative control } \\
(3.0 \mathrm{mg} / \mathrm{kg} \text { DON })\end{array}$} \\
\hline & None & $0.17 \%$ & $0.50 \%$ & None & $0.17 \%$ & $0.50 \%$ & None & $0.17 \%$ & $0.50 \%$ \\
\hline Corn & 15.07 & 14.89 & 14.53 & 15.35 & 15.17 & 14.81 & 15.63 & 15.45 & 15.09 \\
\hline Soybean meal, $46.5 \% \mathrm{CP}$ & 31.58 & 31.60 & 31.62 & 31.25 & 31.26 & 31.29 & 30.92 & 30.93 & 30.96 \\
\hline Hard red winter (HRW) wheat & 50.00 & 50.00 & 50.00 & 25.00 & 25.00 & 25.00 & & & \\
\hline High-DON ${ }^{3}$ HRW wheat & & & & 25.00 & 25.00 & 25.00 & 50.00 & 50.00 & 50.00 \\
\hline Monocalcium phosphate, $21 \% \mathrm{P}$ & 1.05 & 1.05 & 1.05 & 1.05 & 1.05 & 1.05 & 1.05 & 1.05 & 1.05 \\
\hline Limestone & 1.00 & 1.00 & 1.00 & 1.05 & 1.05 & 1.05 & 1.10 & 1.10 & 1.10 \\
\hline Salt & 0.35 & 0.35 & 0.35 & 0.35 & 0.35 & 0.35 & 0.35 & 0.35 & 0.35 \\
\hline L-Lys HCl & 0.33 & 0.33 & 0.33 & 0.33 & 0.33 & 0.33 & 0.33 & 0.33 & 0.33 \\
\hline DL-Met & 0.10 & 0.10 & 0.10 & 0.10 & 0.10 & 0.10 & 0.10 & 0.10 & 0.10 \\
\hline L-Thr & 0.13 & 0.13 & 0.13 & 0.13 & 0.13 & 0.13 & 0.13 & 0.13 & 0.13 \\
\hline Vitamin premix with phytase $e^{4,5}$ & 0.25 & 0.25 & 0.25 & 0.25 & 0.25 & 0.25 & 0.25 & 0.25 & 0.25 \\
\hline Trace mineral premix ${ }^{6}$ & 0.15 & 0.15 & 0.15 & 0.15 & 0.15 & 0.15 & 0.15 & 0.15 & 0.15 \\
\hline AMMC & & 0.17 & 0.50 & & 0.17 & 0.50 & & 0.17 & 0.50 \\
\hline Total & 100 & 100 & 100 & 100 & 100 & 100 & 100 & 100 & 100 \\
\hline \multicolumn{10}{|l|}{ Calculated analysis } \\
\hline \multicolumn{10}{|l|}{$\mathrm{SID}^{7} \mathrm{AA}, \%$} \\
\hline Lys & 1.28 & 1.28 & 1.28 & 1.28 & 1.28 & 1.28 & 1.28 & 1.28 & 1.28 \\
\hline Ile:Lys & 64 & 64 & 64 & 65 & 65 & 65 & 65 & 65 & 65 \\
\hline Leu:Lys & 118 & 118 & 117 & 118 & 118 & 118 & 117 & 117 & 117 \\
\hline Met:Lys & 31 & 31 & 31 & 31 & 31 & 31 & 31 & 31 & 31 \\
\hline Met and Cys:Lys & 57 & 57 & 57 & 57 & 57 & 57 & 57 & 57 & 57 \\
\hline Thr:Lys & 63 & 63 & 63 & 63 & 63 & 63 & 63 & 63 & 63 \\
\hline Trp:Lys & 21.2 & 21.2 & 21.2 & 20.7 & 20.7 & 20.7 & 20.3 & 20.3 & 20.2 \\
\hline Val:Lys & 68 & 68 & 68 & 69 & 69 & 69 & 70 & 70 & 70 \\
\hline Total Lys, \% & 1.43 & 1.43 & 1.43 & 1.43 & 1.43 & 1.43 & 1.43 & 1.43 & 1.43 \\
\hline $\mathrm{ME}, \mathrm{kcal} / \mathrm{kg}$ & 3,183 & 3,179 & 3,165 & 3,181 & 3,177 & 3,165 & 3,181 & 3,175 & 3,164 \\
\hline SID Lys:ME, g/Mcal & 4.02 & 4.03 & 4.04 & 4.02 & 4.03 & 4.04 & 4.02 & 4.03 & 4.05 \\
\hline $\mathrm{CP}, \%$ & 22.7 & 22.7 & 22.6 & 22.6 & 22.6 & 22.6 & 22.6 & 22.6 & 22.6 \\
\hline $\mathrm{Ca}, \%$ & 0.68 & 0.68 & 0.68 & 0.69 & 0.69 & 0.69 & 0.71 & 0.71 & 0.71 \\
\hline $\mathrm{P}, \%$ & 0.68 & 0.68 & 0.68 & 0.69 & 0.69 & 0.69 & 0.71 & 0.71 & 0.70 \\
\hline Available P, \% & 0.50 & 0.50 & 0.50 & 0.51 & 0.51 & 0.51 & 0.51 & 0.51 & 0.51 \\
\hline
\end{tabular}

${ }^{1} \mathrm{DON}=$ deoxynivalenol.

${ }^{2} \mathrm{AMMC}=$ algae-modified montmorillonite clay product (Olmix S.A., Brehan, France).

${ }^{3}$ Analyzed DON concentration in HRW wheat was $6.0 \mathrm{mg} / \mathrm{kg}$ at LDA Laboratories (Ploufragan, France).

${ }^{4}$ Provided per kilogram of premix: 4,409,200 IU vitamin A; 551,150 IU vitamin $\mathrm{D}_{3}$; 17,637 IU vitamin E; 1,764 mg vitamin K; 3,307 mg riboflavin; $11,023 \mathrm{mg}$ pantothenic acid; $19,841 \mathrm{mg}$ niacin; and $15.4 \mathrm{mg}$ vitamin $\mathrm{B}_{12}$.

${ }^{5}$ Phyzyme 600 (Danisco Animal Nutrition, St. Louis, MO) provided 750 phytase units phytase $/ \mathrm{kg}$ and $0.13 \%$ available P released.

${ }^{6}$ Provided per kilogram of premix: $22.0 \mathrm{~g}$ Mn from manganese oxide, $73.4 \mathrm{~g}$ Fe from iron sulfate, $73.4 \mathrm{~g} \mathrm{Zn}$ from zinc sulfate, $11.0 \mathrm{~g}$ Cu from copper sulfate, $198 \mathrm{mg}$ I from calcium iodate, and $198 \mathrm{mg}$ Se from sodium selenite.

${ }^{7}$ Standardized ileal digestible.

the targeted DON level, averaging 1.7 and $3.2 \mathrm{mg} / \mathrm{kg}$ for the 1.5 and $3.0 \mathrm{mg} / \mathrm{kg}$ targets, respectively (Table 10).

A DON $\times$ AMMC interaction (linear, $P<0.05$ ) was observed from d 0 to 7, where increasing AMMC improved ADG in $\mathrm{PC}$ and low-NC diets but decreased ADG in high-NC diets (Table 11). The interaction for ADG appeared to be driven by a tendency for a G:F interaction (linear, $P<0.05$ ) in which increasing AMMC inclusion worsened feed efficiency in high-NC diets, whereas feed efficiency remained similar in pigs fed PC and low-NC diets regardless of AMMC inclusion. Furthermore, a tendency for a DON $\times$ AMMC interaction for feed ef- ficiency (quadratic, $P=0.073$ ) was observed from d 14 to 21 , where increasing AMMC in PC and low-NC diets worsened feed efficiency, whereas in high-NC diets, increasing AMMC initially improved but subsequently worsened $\mathrm{G}: \mathrm{F}$ at the $0.50 \%$ inclusion rate.

For the main effects of DON and AMMC on growth performance (Table 12), from d 0 to $3, \mathrm{ADG}, \mathrm{ADFI}$, and G:F decreased (linear, $P<0.001$ ) with increasing DON concentrations. From d 4 to 7 , increasing DON level progressively worsened ADG $(P<0.05)$, driven not by ADFI but as a consequence of poorer $(P<0.05)$ $\mathrm{G}: \mathrm{F}$. From d 7 to 14 , ADG decreased (linear, $P<0.001$ ) 
Table 8. Nutrient analysis of experimental diets, Exp. 2 (as-fed basis) ${ }^{1}$

\begin{tabular}{|c|c|c|c|c|c|c|c|c|c|}
\hline \multirow{2}{*}{$\begin{array}{l}\text { Item, } \% \\
\text { AMMC }^{3} \text { : }\end{array}$} & \multicolumn{3}{|c|}{$\begin{array}{c}\text { Positive control } \\
\left(<0.5 \mathrm{mg} / \mathrm{kg} \mathrm{DON}^{2}\right)\end{array}$} & \multicolumn{3}{|c|}{$\begin{array}{c}\text { Low negative control } \\
(1.5 \mathrm{mg} / \mathrm{kg} \mathrm{DON})\end{array}$} & \multicolumn{3}{|c|}{$\begin{array}{l}\text { High negative control } \\
(3.0 \mathrm{mg} / \mathrm{kg} \mathrm{DON})\end{array}$} \\
\hline & None & $0.17 \%$ & $0.50 \%$ & None & $0.17 \%$ & $0.50 \%$ & None & $0.17 \%$ & $0.50 \%$ \\
\hline Moisture & 9.77 & 9.60 & 9.93 & 10.04 & 9.77 & 9.89 & 9.97 & 9.66 & 9.75 \\
\hline $\mathrm{CP}$ & 24.9 & 23.8 & 24.2 & 23.4 & 23.2 & 23.3 & 23.5 & 23.7 & 23.5 \\
\hline $\mathrm{ADF}$ & 2.6 & 2.4 & 2.1 & 2.7 & 3.5 & 2.2 & 2.5 & 2.6 & 2.6 \\
\hline NDF & 7.6 & 7.0 & 7.5 & 7.6 & 8.0 & 7.4 & 6.8 & 7.2 & 7.2 \\
\hline Ether extract & 2.4 & 2.6 & 2.5 & 2.6 & 2.9 & 2.6 & 2.6 & 2.8 & 2.7 \\
\hline Ash & 5.14 & 5.31 & 5.53 & 5.53 & 5.61 & 5.57 & 5.65 & 5.73 & 5.96 \\
\hline $\mathrm{Ca}$ & 0.71 & 0.81 & 0.82 & 0.86 & 0.83 & 0.76 & 0.87 & 0.83 & 0.89 \\
\hline $\mathrm{P}$ & 0.74 & 0.67 & 0.68 & 0.69 & 0.69 & 0.71 & 0.69 & 0.71 & 0.74 \\
\hline
\end{tabular}

${ }^{1}$ Samples were analyzed at the University of Missouri Agricultural Experiment Station Chemical Laboratories in Columbia, MO.

${ }^{2} \mathrm{DON}=$ deoxynivalenol.

${ }^{3} \mathrm{AMMC}=$ algae-modified montmorillonite clay (Olmix S.A., Brehan, France).

as DON increased in the diet. This growth reduction was influenced primarily by progressively poorer (quadratic, $P<0.001$ ) G:F as ADFI decreased (quadratic, $P<0.001)$ and then recovered with increasing DON concentrations. From d 14 to 21, increasing DON level tended to decrease (linear, $P=0.087$ ) ADG, and increasing AMMC level tended to reduce (linear, $P=0.094$ ) feed efficiency. Overall (d 0 to 21), increasing DON concentration in nursery pig diets progressively worsened (linear, $P<0.001$ ) ADG and final BW, governed predominantly by a decrease (linear, $P<0.001$ ) in feed efficiency with poorer ADFI (quadratic, $P<0.001$ ) as a

Table 9. Mycotoxin analysis of basal ingredients, Exp. 2 (as-fed basis)

\begin{tabular}{|c|c|c|c|}
\hline \multirow[b]{2}{*}{ Item, $\mathrm{mg} / \mathrm{kg}$} & \multirow[b]{2}{*}{ Ground corn } & \multicolumn{2}{|c|}{ Hard red winter wheat } \\
\hline & & Low DON ${ }^{1}$ & High DON \\
\hline \multicolumn{4}{|l|}{$\overline{\mathrm{NDSU}^{2}}$} \\
\hline DON & $<0.50$ & $<0.50$ & 8.40 \\
\hline \multicolumn{4}{|l|}{ LABOCEA $^{3}$} \\
\hline DON & $\mathrm{NT}^{4}$ & NT & 6.03 \\
\hline De-epoxy DON & NT & NT & 0.02 \\
\hline $15-O$-Acetyl DON & NT & NT & 0.07 \\
\hline 3-Acetyl DON & NT & NT & 0.03 \\
\hline Zearalenone & NT & NT & 0.02 \\
\hline HT-2 Toxin & NT & NT & 0.02 \\
\hline Ergocryptine & NT & NT & 0.08 \\
\hline Ergosine & NT & NT & 0.02 \\
\hline Tenuazonic acid & NT & NT & 0.05 \\
\hline
\end{tabular}

${ }^{1} \mathrm{DON}=$ deoxynivalenol.

${ }^{2}$ North Dakota State University Veterinary Diagnostic Laboratory, Fargo, ND. Samples were sent for an 18-component mycotoxin analysis and analyzed using a variety of mass spectrometry, ELISA, and HPLC methods. Included in the table are mycotoxins found at levels above detection limits.

${ }^{3}$ LABOCEA (Ploufragan, France). Samples were analyzed using a 43-component toxin screen using liquid chromatography/mass spectrometry analysis methods. Included in the table are mycotoxins found at levels above detection limits.

${ }^{4} \mathrm{NT}=$ samples not tested. contributing influence. The addition of AMMC had no effect on overall ADG, ADFI, G:F, or final BW.

\section{DISCUSSION}

The origin of the DON used in studies appears to be important (Eriksen and Petterson, 2004; Etienne and Waché, 2008). At equivalent DON levels, purified sources of DON elicited less severe growth depression compared to naturally contaminated DON sources, even when no other mycotoxins were detected (Trenholm et al., 1994). While this difference is yet to be explained, proposed hypotheses include the presence of other fungal components in naturally contaminated grains that contribute to DON toxicity, differential rates or degree of DON absorption, and potential undervaluation of DON due to the difficulty of analyzing toxin in a complex grain matrix (Etienne and Waché, 2008; Pestka, 2010). Finally, given that potential detoxifying agents are designed to prevent the effects of naturally contaminated feedstuffs, wheat predominately contaminated with DON was identified and used to incorporate into test diets at desired concentrations. Low concentrations of aflatoxin and fumonisin were also detected in Exp. 1 diets but at concentrations well below safe levels, determined as less than $200 \mu \mathrm{g} / \mathrm{kg}$ for aflatoxin and $5 \mathrm{mg} / \mathrm{kg}$ for fumonisins (Thaler and Reese, 2010). Therefore, while multi-toxin interactive effects cannot be totally excluded, in the present study, mycotoxin analyses indicate that the observed growth responses were primarily due to DON.

Although rarely accounted for when testing DONdetoxifying agents, Fusarium pathogens are also known to alter the nutrient content and digestibility of the affected grain. Mätthaus et al. (2004) reported greater CP and ash contents and smaller kernels in wheat inoculated with Fusarium culmorum. Thanh et al. (2015) also observed increased analyzed $\mathrm{N}$ concentrations in diets containing DON-contaminated wheat. However, Dänicke et 
Table 10. Mycotoxin analysis of experimental diets, Exp. 2 (as-fed basis) ${ }^{1}$

\begin{tabular}{|c|c|c|c|c|c|c|c|c|c|}
\hline \multirow{2}{*}{$\begin{array}{l}\text { Item } \\
\text { AMMC }^{3} \text { : }\end{array}$} & \multicolumn{3}{|c|}{$\begin{array}{c}\text { Positive control } \\
\left(<0.5 \mathrm{mg} / \mathrm{kg} \mathrm{DON}^{2}\right)\end{array}$} & \multicolumn{3}{|c|}{$\begin{array}{c}\text { Low negative control } \\
(1.5 \mathrm{mg} / \mathrm{kg} \text { DON })\end{array}$} & \multicolumn{3}{|c|}{$\begin{array}{l}\text { High negative control } \\
(3.0 \mathrm{mg} / \mathrm{kg} \text { DON })\end{array}$} \\
\hline & None & $0.17 \%$ & $0.50 \%$ & None & $0.17 \%$ & $0.50 \%$ & None & $0.17 \%$ & $0.50 \%$ \\
\hline $\mathrm{DON}, \mathrm{mg} / \mathrm{kg}$ & $<0.5$ & $<0.5$ & $<0.5$ & 1.7 & 1.8 & 1.7 & 3.4 & 2.7 & 3.5 \\
\hline
\end{tabular}

al. (2004b) reported no differences in CP concentrations between wheat sources. In the present study, the highDON wheat source was generally lower in CP and AA content in Exp. 1 and greater in AA content in Exp. 2. While Fusarium-induced fluctuations in nutrient content appear inconsistent, they highlight the need to account for differences during diet formulation so that the mycotoxin-specific effects and efficacy of detoxifying agents can be interpreted accurately. Contamination with Fusarium can also impact nutrient digestibility. In a pig growth study by Thanh et al. (2015), pigs fed DON-contaminated diets $(4.6 \mathrm{mg} / \mathrm{kg})$ had reduced DM, energy, and fat digestibility. However, this conflicts with previous reports where feeding DON-contaminated diets had no impact (Dänicke et al., 2004b) or even increased total tract nutrient digestibility in feed-restricted pigs (Dänicke et al., 2004a). Authors attributed these fluctuations in digestibility to variations in the grain varieties used, production of cell wall-degrading enzymes by Fusarium fungi, and DON-induced changes in intestinal absorption capacity (Bracarense et al., 2012).

Unlike some other mycotoxins, the effects of DON on tissue composition and blood metabolites are negligible and well-characterized (Swamy et al., 2002; Madson et al., 2014). Accordingly, these analyses were not measured in the present study. From a growth perspective, in the present studies, feeding diets containing approximately 1.7 or $3.2 \mathrm{mg} / \mathrm{kg}$ DON in Exp. 2 and 6.6 $\mathrm{mg} / \mathrm{kg}$ DON in Exp. 1 decreased ADG by 10, 13, and $20 \%$, respectively, compared to controls. A pair of meta-analyses (Dänicke, 2002; Etienne and Waché, 2008) both calculated that once dietary DON exceeds $1 \mathrm{mg}$ / $\mathrm{kg}$, BW gain decreases by approximately $7 \%$ for each additional $\mathrm{mg}$ of DON. In the present study, pigs fed low levels of DON in Exp. 2 generally followed these predictive equations, but the effects of feeding $6.6 \mathrm{mg} /$ $\mathrm{kg}$ DON in Exp. 1 were not as severe as projected.

While it is known that DON is more rapidly and efficiently absorbed (55\%) in pigs compared to other species and that pigs have limited ability to metabolize DON into less toxic forms (Prelusky et al., 1988; Goyarts and Dänicke, 2006; Wu et al., 2010), the variability in toxicity between individual pigs is not well characterized. During Exp. 1, within pen CV in BW in- creased when pigs were fed DON-contaminated diets. This observation indicates that some pigs may be more sensitive to DON than others, may develop a tolerance to DON more rapidly, or may have a greater ability to metabolize DON. To our knowledge, the effects of DON on $\mathrm{BW}$ variation between similarly treated pigs have not been previously reported, but future studies should attempt to clarify this observation. Unfortunately, pens of pigs in Exp. 2 were not initially balanced for BW variation, and thus changes over time could not be evaluated.

In most pig growth studies with DON, decreased feed intake is the most commonly observed effect. This reduction in intake appears to be primarily associated with altered neuroendocrine signaling in the digestive and central nervous systems of the pig, particularly via elevated levels of serotonin (Prelusky, 1994; Rotter et al., 1996). Known to reduce intestinal motility and gastric emptying in rodents, this serotonergic effect is likely to impact pigs in a similar fashion (Fioramonti et al., 1993). However, Ossenkopp et al. (1994) also demonstrated that DON causes conditioned taste aversion in rats, mediated by the area postrema of the brain, which is likely to contribute to the anorexic effects of DON.

Previous reports indicate that unless DON levels exceed $1 \mathrm{mg} / \mathrm{kg}$, the effects on pig growth are minimal; however, each additional milligram per kilogram of DON is predicted to decrease ADFI by 4 to $5 \%$ (reviewed by Dänicke [2002] and Etienne and Waché [2008]). In the present experiments, the effects of DON on feed intake were often less severe. In Exp. 1, feeding $6.6 \mathrm{mg} / \mathrm{kg}$ DON only reduced ADFI by $10 \%$. In Exp. 2 , feeding $1.7 \mathrm{mg} / \mathrm{kg}$ DON elicited an $8 \%$ decrease in ADFI, which is consistent with the prediction equation, but interestingly, ADFI was only reduced by $2 \%$ at the greater DON concentration of $3.2 \mathrm{mg} / \mathrm{kg}$. In Exp. 1, ADFI remained suppressed throughout the study but to a much lesser extent during the last 2 wk compared to the initial 2 wk (6 vs. 22\%). In Exp. 2, lower DON levels resulted in negligible feed intake effects after the initial exposure period. These results are consistent with earlier reports, where feed intake was often restored after 7 to $14 \mathrm{~d}$ if diets contained less than $3 \mathrm{mg} / \mathrm{kg}$ DON (Lun et al., 1985; Grosjean et al., 2002; Rempe et al., 2013). These observations also support the hypothesis 
Table 11. Interactive effects of an algae-modified montmorillonite clay (AMMC) on growth performance of nursery pigs fed diets contaminated with low levels of deoxynivalenol (DON), Exp. $2^{1,2}$

\begin{tabular}{|c|c|c|c|c|c|c|c|c|c|c|c|c|}
\hline \multirow{2}{*}{$\begin{array}{l}\text { Item } \\
\text { AMMC: }\end{array}$} & \multicolumn{3}{|c|}{$\begin{array}{c}\text { Positive control } \\
(<0.5 \mathrm{mg} / \mathrm{kg} \mathrm{DON})\end{array}$} & \multicolumn{3}{|c|}{$\begin{array}{c}\text { Low negative control } \\
(1.5 \mathrm{mg} / \mathrm{kg} \mathrm{DON})\end{array}$} & \multicolumn{3}{|c|}{$\begin{array}{c}\text { High negative control }^{3} \\
(3.0 \mathrm{mg} / \mathrm{kg} \mathrm{DON})\end{array}$} & \multirow[b]{2}{*}{ SEM } & \multicolumn{2}{|c|}{$\begin{array}{l}\text { Probability, } P< \\
\text { DON } \times \text { AMMC }\end{array}$} \\
\hline & None & $0.17 \%$ & $0.50 \%$ & None & $0.17 \%$ & $0.50 \%$ & None & $0.17 \%$ & $0.50 \%$ & & Linear & Quad \\
\hline \multicolumn{13}{|l|}{$\mathrm{d} 0$ to 3} \\
\hline ADG, $g$ & 409 & 387 & 418 & 325 & 280 & 346 & 275 & 292 & 198 & 34.8 & 0.049 & 0.124 \\
\hline ADFI, $g$ & 629 & 615 & 631 & 549 & 539 & 580 & 519 & 526 & 531 & 27.3 & 0.862 & 0.691 \\
\hline G:F & 0.650 & 0.630 & 0.657 & 0.590 & 0.513 & 0.597 & 0.524 & 0.555 & 0.370 & 0.042 & 0.019 & 0.069 \\
\hline \multicolumn{13}{|l|}{ d 4 to 7} \\
\hline ADG, $g$ & 426 & 394 & 435 & 363 & 382 & 383 & 389 & 367 & 360 & 28.0 & 0.446 & 0.397 \\
\hline ADFI, $g$ & 508 & 502 & 528 & 540 & 513 & 490 & 544 & 540 & 499 & 34.5 & 0.233 & 0.815 \\
\hline G:F & 0.865 & 0.801 & 0.849 & 0.667 & 0.765 & 0.808 & 0.728 & 0.683 & 0.715 & 0.065 & 0.996 & 0.301 \\
\hline \multicolumn{13}{|l|}{ d 7 to 14} \\
\hline ADG, $g$ & 576 & 572 & 599 & 537 & 490 & 527 & 484 & 481 & 506 & 32.2 & 0.987 & 0.315 \\
\hline ADFI, $g$ & 832 & 885 & 924 & 760 & 722 & 767 & 908 & 820 & 882 & 53.7 & 0.258 & 0.843 \\
\hline G:F & 0.70 & 0.646 & 0.651 & 0.710 & 0.689 & 0.700 & 0.547 & 0.596 & 0.583 & 0.031 & 0.272 & 0.722 \\
\hline \multicolumn{13}{|l|}{ d 14 to 21} \\
\hline ADG, $g$ & 672 & 688 & 652 & 667 & 624 & 603 & 639 & 643 & 641 & 20.9 & 0.527 & 0.277 \\
\hline ADFI, $g$ & 963 & 955 & 975 & 931 & 933 & 920 & 980 & 919 & 970 & 84.9 & 0.851 & 0.424 \\
\hline $\mathrm{G}: \mathrm{F}$ & 0.71 & 0.728 & 0.680 & 0.726 & 0.678 & 0.663 & 0.658 & 0.705 & 0.664 & 0.064 & 0.493 & 0.073 \\
\hline \multicolumn{13}{|l|}{ d 0 to 21} \\
\hline ADG, $g$ & 556 & 550 & 559 & 517 & 484 & 499 & 488 & 486 & 479 & 14.6 & 0.618 & 0.268 \\
\hline ADFI, $g$ & 785 & 797 & 824 & 745 & 726 & 739 & 807 & 758 & 788 & 25.7 & 0.300 & 0.884 \\
\hline G:F & 0.71 & 0.691 & 0.681 & 0.696 & 0.669 & 0.678 & 0.609 & 0.643 & 0.608 & 0.025 & 0.559 & 0.177 \\
\hline \multicolumn{13}{|l|}{ Pig BW, kg } \\
\hline $\mathrm{d} 0$ & 11.4 & 11.4 & 11.4 & 11.4 & 11.4 & 11.4 & 11.4 & 11.4 & 11.4 & 0.24 & 0.965 & 0.996 \\
\hline d 21 & 23.1 & 23.0 & 23.2 & 22.3 & 21.6 & 21.9 & 21.7 & 21.6 & 21.5 & 0.48 & 0.740 & 0.488 \\
\hline
\end{tabular}

${ }^{1} \mathrm{~A}$ total of 360 barrows (PIC 1050; initially $45 \mathrm{~d}$ of age) were used in a 21-d experiment with 8 pens per treatment and 5 pigs per pen. All diets were fed in meal form.

${ }^{2}$ Algae-modified montmorillonite clay (AMMC; Olmix S. A., Brehan, France).

${ }^{3}$ Denotes formulated levels. High-DON wheat $(6.0 \mathrm{mg} / \mathrm{kg})$ was used to incorporate DON into diets at desired concentrations.

that pigs develop some degree of adaptation to DON after the initial exposure period (Dersjant-Li et al., 2003). Development of tolerance to the anorectic effects of DON is congruent with observations that DON-induced taste aversion diminishes with time, which is common among anorexic compounds dependent on serotonergic mechanisms (reviewed by Rotter et al. [1996]).

While the effects of DON on feed intake are wellcharacterized, DON-induced changes in feed efficiency are multidimensional and less understood. At the cellular level, DON causes cell death via apoptosis and inhibits protein synthesis by obstructing translation at the ribosomal level, leading to ribotoxic stress syndrome (reviewed by Pestka [2010]). These effects are known to have the greatest impact on rapidly dividing cells, such as epithelial and immune cells in the gastrointestinal tract (GIT; Van De Walle et al., 2010). Thus, DON contamination causes compromised barrier function by decreasing the expression of tight junction proteins (Van De Walle et al., 2010; Pinton et al., 2012) and can increase the susceptibility of the GIT to bacterial infections (Grenier and Applegate, 2013). Exposure to DON also decreases the rate of epithelial cell division, resulting in flattened intestinal villi and reducing the absorptive surface area for nutrient uptake (Bracarense et al., 2012). Combined with DON-induced leukocyte apoptosis, which suppresses immune function (Pestka et al., 2004), these effects are likely to contribute to growth retardation. Conceivably, these effects indicate that the toxicity of DON might be dramatically greater if exposure were to occur alongside bacterial infection. Nonetheless, the modulation of these digestive and immune functions by DON does not always affect animal growth parameters (Grenier and Applegate, 2013).

Feeding moderate levels of DON (3.5 to $6.6 \mathrm{mg}$ DON) for extended periods ( 95 to $115 \mathrm{~d}$ ) during the grow-finish phase consistently worsened feed efficiency in 3 experiments (Bergsjø et al., 1993; Dänicke et al., 2004a; Patience et al., 2014). However, in short-term studies on young pigs, the effects of DON on feed efficiency appear more transitory. In several growth studies, overall G:F was not affected by DON exposure (Friend et al., 1984; Pollman et al., 1985; Grosjean et al., 2002). Nonetheless, when reported by phase, pigs regularly have poorer G:F during the initial period (Pollman et al., 1985; 
Table 12. Main effects of deoxynivalenol (DON) and algae-modified montmorillonite clay (AMMC; Olmix S. A., Brehan, France) on nursery pig performance, Exp. $2^{1}$

\begin{tabular}{|c|c|c|c|c|c|c|c|c|c|c|c|c|}
\hline \multirow[b]{3}{*}{ Item } & \multirow{2}{*}{\multicolumn{3}{|c|}{$\begin{array}{c}\text { Formulated } \mathrm{DON}^{2}, \\
\mathrm{mg} / \mathrm{kg}\end{array}$}} & \multirow[b]{3}{*}{ SEM } & \multirow{2}{*}{\multicolumn{3}{|c|}{ AMMC, $\%$}} & \multirow[b]{3}{*}{ SEM } & \multicolumn{4}{|c|}{ Probability, $P<$} \\
\hline & & & & & & & & & \multicolumn{2}{|c|}{ DON } & \multicolumn{2}{|c|}{ AMMC } \\
\hline & $<0.5$ & 1.5 & 3.0 & & None & $0.17 \%$ & $0.50 \%$ & & Linear & Quad & Linear & Quad \\
\hline \multicolumn{13}{|l|}{ d 0 to 3} \\
\hline ADG, $g$ & 405 & 317 & 255 & 27.9 & 337 & 320 & 321 & 27.9 & 0.001 & 0.480 & 0.503 & 0.537 \\
\hline ADFI, $g$ & 625 & 556 & 525 & 23.0 & 565 & 560 & 581 & 23.0 & 0.001 & 0.144 & 0.222 & 0.411 \\
\hline G:F & 0.646 & 0.567 & 0.483 & 0.028 & 0.588 & 0.566 & 0.541 & 0.028 & 0.001 & 0.938 & 0.144 & 0.817 \\
\hline \multicolumn{13}{|l|}{ d 4 to 7} \\
\hline ADG, $g$ & 418 & 376 & 372 & 16.2 & 393 & 380.9 & 392.6 & 16.2 & 0.047 & 0.342 & 0.915 & 0.557 \\
\hline ADFI, $g$ & 513 & 514 & 528 & 24.9 & 531 & 518 & 506 & 24.9 & 0.536 & 0.774 & 0.312 & 0.840 \\
\hline G:F & 0.838 & 0.747 & 0.709 & 0.040 & 0.753 & 0.750 & 0.790 & 0.040 & 0.015 & 0.549 & 0.425 & 0.727 \\
\hline \multicolumn{13}{|l|}{ d 7 to 14} \\
\hline ADG, g & 582 & 518 & 490 & 27.3 & 532 & 514 & 544 & 27.3 & 0.001 & 0.218 & 0.329 & 0.148 \\
\hline ADFI, $g$ & 880 & 750 & 870 & 41.3 & 833 & 809 & 858 & 41.3 & 0.764 & 0.001 & 0.352 & 0.293 \\
\hline $\mathrm{G}: \mathrm{F}$ & 0.665 & 0.700 & 0.575 & 0.018 & 0.652 & 0.644 & 0.645 & 0.018 & 0.001 & 0.001 & 0.809 & 0.800 \\
\hline \multicolumn{13}{|l|}{ d 14 to 21} \\
\hline ADG, $\mathrm{g}$ & 671 & 631 & 641 & 12.0 & 659 & 652 & 632 & 12.0 & 0.087 & 0.103 & 0.103 & 0.935 \\
\hline ADFI, $g$ & 965 & 928 & 956 & 80.6 & 958 & 936 & 955 & 80.6 & 0.754 & 0.166 & 0.949 & 0.370 \\
\hline $\mathrm{G}: \mathrm{F}$ & 0.705 & 0.689 & 0.676 & 0.061 & 0.697 & 0.704 & 0.669 & 0.061 & 0.124 & 0.940 & 0.094 & 0.356 \\
\hline \multicolumn{13}{|l|}{ d 0 to 21} \\
\hline ADG, $g$ & 555 & 500 & 484 & 9.0 & 520 & 507 & 513 & 9.0 & 0.001 & 0.053 & 0.644 & 0.292 \\
\hline ADFI, $g$ & 802 & 737 & 784 & 17.3 & 779 & 760 & 784 & 17.3 & 0.357 & 0.001 & 0.629 & 0.233 \\
\hline G:F & 0.694 & 0.681 & 0.620 & 0.021 & 0.672 & 0.668 & 0.656 & 0.021 & 0.001 & 0.039 & 0.206 & 0.889 \\
\hline \multicolumn{13}{|l|}{ Pig BW, kg } \\
\hline $\mathrm{d} 0$ & 11.4 & 11.4 & 11.4 & 0.14 & 11.4 & 11.4 & 11.4 & 0.14 & 0.999 & 0.979 & 0.968 & 0.998 \\
\hline $\mathrm{d} 21$ & 23.1 & 21.9 & 21.6 & 0.28 & 22.3 & 22.0 & 22.2 & 0.28 & 0.001 & 0.220 & 0.789 & 0.510 \\
\hline
\end{tabular}

${ }^{1} \mathrm{~A}$ total of 360 barrows (PIC 1050; initially $45 \mathrm{~d}$ of age) were used in a 21-d experiment with 24 replicate pens per treatment and 5 pigs per pen. All diets were fed in meal form.

${ }^{2}$ Denotes formulated levels. High-DON wheat $(6.0 \mathrm{mg} / \mathrm{kg})$ was used to incorporate DON into diets at desired concentrations.

Frobose et al., 2015). This is consistent with the poorer $\mathrm{G}: \mathrm{F}$ reported in experiments with shorter durations (5 to $9 \mathrm{~d}$; He et al., 1993; Li et al., 2011). Similar observations were observed in both of the present experiments, with severely reduced G:F during the first $3 \mathrm{~d}$ of DON exposure, lessening slightly by $\mathrm{d} 7$, and no longer present thereafter. This initial DON-induced feed efficiency depression still had a more marked negative effect on overall ADG than the impact of DON on feed intake. In Exp. 1 , it is likely that the greater DON levels fed $(6.6 \mathrm{mg} / \mathrm{kg})$ contributed to the poorer feed efficiency observed, likely mediated by previously described effects, such as suppressed immune and GIT function. However, in Exp. 2, lower levels of DON were fed (1.7 and $3.2 \mathrm{mg} / \mathrm{kg}$ ) and yet the effects of DON on G:F were just as severe (11\%) as in Exp. 1. Health challenge may have contributed to the more marked effect of DON on feed efficiency, as pigs in Exp. 2 were concomitantly affected by influenza, which originated from the source sow farm. Moreover, in both experiments, the authors observed that pigs fed DON-contaminated diets required frequent adjustment of feeders to maintain the predetermined $50 \%$ pan coverage, with DON-fed pigs being more likely to sort through the feed leading to complete feed pan coverage. This would be congruent with earlier reports that the illness-inducing effects of DON can induce conditioned taste aversion that lessens over time (Osweiler et al., 1990; Ossenkopp et al., 1994). This observation requires additional investigation, but feed wastage during this period would also contribute to poorer feed efficiency. Finally, one may question whether pigs exposed to DON in field conditions are consistently exposed to DON levels great enough to allow tolerance to develop. In large-scale commercial situations, pigs are more likely to be fed diets containing multiple sources of cereal grains and, therefore, may be exposed to DON intermittently rather than continuously as has been provided in almost all experiments testing DON effects. Currently, it is unknown whether the severity of growth effects may differ when pigs are intermittently exposed to DON compared to continuous DON exposure.

Some technical treatments applied prior to feeding contaminated grains are known to partially or completely detoxify DON (e.g., physical separation, inactivation by heat/microbes, and ozone or ammonia gas treatment); however, these methods have been too labor- and costintensive to merit widespread commercial adoption or 
have failed to meet government regulations (McKenzie et al., 1997; Döll and Dänicke, 2004; Young et al., 2007; Li et al., 2011). Supplementing contaminated diets with detoxifying agents is widely regarded as a more practical approach; however, currently-available feed additives have generally failed to alleviate the effects of DON (Ramos et al., 1996; Huwig et al., 2001; Awad et al., 2010). While previous attempts to use mineral adsorbing agents on nonpolar mycotoxins such as DON have been ineffective (Döll and Dänicke, 2004; Döll et al., 2005), the use of AMMC had not been previously tested in vivo.

Through a patented process (Amadeite; Olmix S.A., Brehan, France), the structure of the montmorillonite is modified using ulvans extracted from green seaweed (Lahaye and Robic, 2007). These water-soluble polysaccharides act as pillars between layers and result in a 10 -fold increase of the inter-laminar space. This transformation enhanced the DON adsorptive capacity of the algae-modified montmorillonite clay (AMMC; Olmix S.A., Brehan, France) by $40 \%$ in a gastrointestinal model at low inclusion rates $(0.1 \%$; Havenaar and Demais, 2006). Nevertheless, regardless of the concentration of AMMC used and the level of DON in the diet, AMMC failed to alleviate DON-induced growth suppression in both experiments. The lack of an AMMC response in Exp. 2, when diets were fed in meal form, indicates that the heat and pressure present during pelleting was unlikely responsible for the lack of a response to AMMC in Exp. 1. Since factorial designs were used in both studies, we were able to demonstrate that AMMC supplementation also elicited no negative effects on toxin-free PC pigs. This is of note since a review by Döll and Dänicke (2003) revealed that potential detoxifying agents were actually more likely to decrease rather than improve performance in DON-contaminated diets. In many past in vivo studies, potential detoxifying agents have only been tested in the DON-exposed group and not added to the toxin-free diet, failing to demonstrate any unspecific effects the agent may have in toxin-free control pigs. This inadequate experimental design limits interpretation of results when testing potential detoxifying agents.

In the present study, fluctuations in nutrient content in DON-contaminated vs. toxin-free wheat reiterate the importance of accounting for these differences in studies assessing the impact of DON and potential detoxifying agents. Though DON contamination resulted in similar overall growth reductions to those seen in previous reports, these experiments indicate that the effects of DON on feed efficiency may be more severe than previously thought. Time-dependent changes observed for feed intake and efficiency also appear to be important in understanding how swine producers should address future DON contamination situations. Depending on the growth stage and DON level in the diet, pigs appear to develop some tolerance to DON. However, the impact of intermittent, repeated exposure to DON deserves additional attention, as it may actually be more often observed in field situations. Despite novel processing methods, algae-modified montmorillonite clay was ineffective at preventing the adverse effects of DON on nursery pig growth performance.

\section{LITERATURE CITED}

Awad, W. A., K. Ghareeb, J. Böhm, and J. Zentek. 2010. Decontamination and detoxification strategies for the Fusarium mycotoxin deoxynivalenol in animal feed and the effectiveness of microbial degradation. Food Addit. Contam. Part A Chem. Anal. Control Expo. Risk Assess. 27:510-520.

Bergsjø, B., W. Langseth, I. Nafstad, J. H. Jansen, and H. J. S. Larsen. 1993. The effects of naturally deoxynivalenol-contaminated oats on the clinical condition, blood parameters, performance and carcass composition of growing pigs. Vet. Res. Commun. 17:283-294.

Bracarense, A.-P. F. L., J. Lucioli, B. Grenier, G. D. Pacheco, W.-D. Moll, G. Schatzmayr, and I. P. Oswald. 2012. Chronic ingestion of deoxynivalenol and fumonisin, alone or in interaction, induces morphological and immunological changes in the intestine of piglets. Br. J. Nutr. 107:1776-1786.

CAST. 2003. Mycotoxins: Risks in plant, animal, and human systems. Report no. 116. Council for Agricultural Science and Technology, Ames, IA.

Dänicke, S. 2002. Fusarium toxins in animal nutrition. Lohmann Information 27:29-37.

Dänicke, S., H. Valenta, S. Döll, M. Ganter, and G. Flachowsky. 2004a. On the effectiveness of a detoxifying agent in preventing fusariotoxicosis in fattening pigs. Anim. Feed Sci. Technol. 114:141-157.

Dänicke, S., H. Valenta, F. Klobasa, S. Döll, M. Ganter, and G. Flachowsky. 2004b. Effects of graded levels of Fusarium toxin contaminated wheat in diets for fattening pigs on growth performance, nutrient digestibility, deoxynivalenol balance and clinical serum characteristics. Arch. Anim. Nutr. 58:1-17.

Dersjant-Li, Y., M. W. A. Verstegen, and W. J. J. Gerrits. 2003. The impact of low concentrations of aflatoxin, deoxynivalenol or fumonisin in diets on growing pigs and poultry. Nutr. Res. Rev. 16:223-239.

Döll, S., and S. Dänicke. 2003. On the efficacy of detoxifying agents in the prevention of fusariotoxicosis - a critical evaluation of the situation. Mycotoxin Res. 19:185-189.

Döll, S., and S. Dänicke. 2004. In vivo detoxification of Fusarium toxins. Arch. Anim. Nutr. 58:419-441.

Döll, S., S. Gericke, S. Dänicke, J. Raila, K.-H. Ueberschar, H. Valenta, U. Schnurrbusch, F. J. Schwiegert, and G. Flachowsky. 2005. The efficacy of a modified aluminosilicate as a detoxifying agent in Fusarium toxin contaminated maize containing diet for piglets. J. Anim. Physiol. Anim. Nutr. 89:342-358.

EFSA. 2009. Review of mycotoxin-detoxifying agents used as feed additives: Mode of action, efficacy and feed/food safety. European Food Safety Association, Parma, Italy.

Eriksen, G. S., and H. Petterson. 2004. Toxicological evaluation of trichothecenes in animal feed. Anim. Feed Sci. Technol. 114:205-239.

Etienne, M., and Y. Waché. 2008. Biological and physical effects of deoxynivalenol (DON) in the pig. In: I. Oswald and I. Taranu, editors, Mycotoxins in farm animals. Transworld Research Network, Kerala, India. p. 113-130. 
Fioramonti, J., C. Dupuy, J. Dupuy, and L. Bueno. 1993. The mycotoxin, deoxynivalenol, delays gastric emptying through serotonin-3 receptors in rodents. J. Pharmacol. Exp. Ther. 266:1255-1260.

Forsyth, D. M., Y. Yoshizawa, N. Morooka, and J. Tuite. 1977. Emetic and feed refusal activity of deoxynivalenol in swine. Appl. Environ. Microbiol. 34:547-552.

Friend, D. W., H. L. Trenholm, J. C. Young, B. K. Thompson, and K. E. Hartin. 1984. Effect of adding potential vomitoxin (deoxynivalenol) detoxicants or a F. graminearum inoculated corn supplement to wheat diets fed to pigs. Can. J. Anim. Sci. 64:733-741.

Frobose, H. L., E. D. Fruge, M. D. Tokach, E. L. Hansen, J. M. DeRouchey, S. S. Dritz, R. D. Goodband, and J. L. Nelssen. 2015. The effects of deoxynivalenol-contaminated corn dried distillers grains with solubles in nursery pig diets and potential for mitigation by commercial feed additives. J. Anim. Sci. 93:1074-1088.

Goyarts, T., and S. Dänicke. 2006. Bioavailability of the Fusarium toxin deoxynivalenol (DON) from naturally contaminated wheat for the pig. Toxicol. Lett. 163:171-182.

Grenier, B., and T. J. Applegate. 2013. Modulation of intestinal functions following mycotoxin ingestion: Meta-analysis of published experiments in animals. Toxins (Basel) 5:396-430.

Grosjean, F., I. Taranu, F. Skiba, P. Callu, and I. Oswald. 2002. Comparisons of different naturally Fusarium-contaminated wheats with uncontaminated wheats in weaned piglet diets. J. Rech. Porcine Fr. 34:333-339.

Groves, F., L. Zhang, Y.-S. Chang, P. F. Ross, H. Casper, W. P. Norred, W. C. You, and J. F. Faumeni. 1999. Fusarium mycotoxins in corn and corn products in a high-risk area for gastric cancer in Shandong Province, China. J. Assoc. Off. Anal. Chem. 82:657662.

Havenaar, R., and H. Demais. 2006. Efficacy of sequestrant/chelator Amadeite in the binding of mycotoxins during transit through a dynamic gastrointestinal model (TIM) simulating the GI conditions of pigs. In: Proc. 4th World Mycotoxin Forum, Cincinnati, $\mathrm{OH}$.

He, P., L. G. Young, and C. Forsberg. 1993. Microbially detoxified vomitoxin-contaminated corn for young pigs. J. Anim. Sci. 71:963-967.

Huwig, A., S. Freimund, O. Kappeli, and H. Dutler. 2001. Mycotoxin detoxification of animal feed by different adsorbents. Toxicol. Lett. 122:179-188.

Lahaye, M., and A. Robic. 2007. Structure and functional properties of ulvan, a polysaccharide from green seaweeds. Biomacromolecules 8:1765-1774.

Li, X.-Z., C. Zhu, C. F. M. de Lange, T. Zhou, J. He, H. Yu, J. Gong, and J. C. Young. 2011. Efficacy of detoxification of deoxynivalenol-contaminated corn by Bacillus sp. LS100 in reducing the adverse effects of the mycotoxin on swine growth performance. Food Addit. Contam. 28:894-901.

Lun, A. K., L. G. Young, and J. H. Lumsden. 1985. The effects of vomitoxin and feed intake on the performance and blood characteristics of young pigs. J. Anim. Sci. 61:1178-1185.

Madson, D. M., S. M. Ensley, J. F. Patience, P. C. Gauger, and R. G. Main. 2014. Diagnostic assessment and lesion evaluation of chronic deoxynivalenol ingestion in growing swine. J. Swine Health Prod. 22:78-83.

Mätthaus, K., S. Dänicke, W. Vahjen, O. Simon, J. Wang, H. Valenta, K. Meyer, A. Strumpf, H. Ziesenib, and G. Flachowsky. 2004. Progression of mycotoxin and nutrient concentrations in wheat after inoculation with Fusarium culmorum. Arch. Anim. Nutr. 58:19-35.
McKenzie, K. S., A. B. Sarr, K. Mayura, R. H. Bailey, D. R. Miller, T. D. Rogers, W. P. Norred, K. A. Voss, R. D. Plattner, L. F. Kubena, and T. D. Phillips. 1997. Oxidative degradation and detoxification of mycotoxins using a novel source of ozone. Food Chem. Toxicol. 35:807-820.

NRC. 2012. Nutrient requirements of swine. 11th rev. ed. Natl. Acad. Press, Washington, DC.

Ossenkopp, K. P., M. Hirst, and W. A. Rapley. 1994. Deoxynivalenol (vomitoxin)-induced conditioned taste aversions in rats are mediated by the chemosensitive area postrema. Pharmacol. Biochem. Behav. 47:363-367.

Osweiler, G. D., D. L. Hopper, and B. M. DeBey. 1990. Taste aversion in swine induced by deoxynivalenol. J. Anim. Sci. 68(Supp. 1):403.

Patience, J. F., A. J. Myers, S. Ensley, B. M. Jacobs, and D. Madson. 2014. Evaluation of two mycotoxin mitigation strategies in grow-finish swine diets containing cord dried distillers grains with solubles naturally contaminated with deoxynivalenol. J. Anim. Sci. 92:620-626.

Pestka, J. J. 2010. Deoxynivalenol: Mechanisms of action, human exposure, and toxicological relevance. Arch. Toxicol. 84:663-679.

Pestka, J. J., W. S. Lin, and E. R. Miller. 1987. Emetic activity of the trichothecene 15-acetyldeoxynivalenol in swine. Food Chem. Toxicol. 25:855-858.

Pestka, J. J., H.-R. Zhou, Y. Moon, and Y. J. Chung. 2004. Cellular and molecular mechanisms for immune modulation by deoxynivalenol and other trichothecenes: Unraveling a paradox. Toxicol. Lett. 153:61-73.

Pinton, P., D. Tsybulskyy, J. Lucioli, J. Laffitte, P. Callu, F. Lyazhri, F. Grosjean, A. P. Bracarense, M. Kolf-Clauw, and I. P. Oswald. 2012. Toxicity of deoxynivalenol and its acetylated derivatives on the intestine: Differential effects on morphology, barrier function, tight junction proteins and mitogen-activated protein kinases. Toxicol. Sci. 130:180-190.

Pollman, D. S., B. A. Koch, L. M. Seitz, H. E. Mohr, and G. A. Kennedy. 1985. Deoxynivalenol-contaminated wheat in swine diets. J. Anim. Sci. 60:239-247.

Prelusky, D. B. 1994. The effect of deoxynivalenol on serotoninergic neurotransmitter levels in pig blood. J. Environ. Sci. Health B 29:1203-1218.

Prelusky, D. B., K. E. Hartin, H. L. Trenholm, and J. D. Miller. 1988. Pharmacokinetic fate of ${ }^{14} \mathrm{C}$-labeled deoxynivalenol in swine. Fundam. Appl. Toxicol. 10:276-286.

Ramos, A.-J., J. Fink-Gremmels, and E. Hernandez. 1996. Prevention of toxic effects of mycotoxins by means of nonnutritive adsorbent compounds. J. Food Prot. 59:631-641.

Rempe, I., S. Kersten, U. Brezine, K. Hermeyer, A. Beineke, and S. Dänicke. 2013. Time-dependent effects of graded levels of Fusarium toxin-contaminated maize in diets for female piglets. World Mycotoxin J. 6:51-63.

Rodrigues, I., and K. Naehrer. 2012. A three-year survey on the worldwide occurrence of mycotoxins in feedstuffs and feed. Toxins (Basel) 4:663-675.

Rotter, B. A., D. B. Prelusky, and J. J. Pestka. 1996. Toxicology of deoxynivalenol (vomitoxin). J. Toxicol. Environ. Health 48:1-34.

Schell, T. C., M. D. Lindemann, E. T. Kornegay, D. J. Blodgett, and J. A. Doerr. 1993. Effectiveness of different types of clay for reducing the detrimental effects of aflatoxin-contaminated diets on performance and serum profiles of weanling pigs. J. Anim. Sci. 71:1226-1231. 
Swamy, H. V. L. N., T. K. Smith, E. J. MacDonald, H. J. Boermans, and E. J. Squires. 2002. Effects of feeding a blend of grains naturally contaminated with Fusarium mycotoxins on swine performance, brain regional neurochemistry, and serum chemistry and the efficacy of a polymeric glucomannan mycotoxin adsorbent. J. Anim. Sci. 80:3257-3267.

Thaler, B., and D. E. Reese. 2010. Utilization of weather stressed feedstuffs in swine. In: D. J. Meisinger, editor, National swine nutrition guide. U.S. Pork Center of Excellence, Ames, IA. p. 207-213.

Thanh, B. V. L., M. Lessard, Y. Chorfi, and F. Guay. 2015. The efficacy of anti-mycotoxin feed additives in preventing the adverse effects of wheat naturally contaminated with Fusarium mycotoxins on performance, intestinal barrier function and nutrient digestibility and retention in weanling pigs. Can. J. Anim. Sci. 95:197-209.
Trenholm, H. L., B. C. Foster, L. L. Charmley, B. K. Thompson, K. E. Hartin, R. W. Coppock, and M. A. Albassam. 1994. Effects of feeding diets containing Fusarium (naturally) contaminated wheat or pure deoxynivalenol (DON) in growing pigs. Can. J. Anim. Sci. 74:361-369.

Van De Walle, J., T. Sergent, N. Piront, O. Toussaint, Y.-J. Schneider, and Y. Larondelle. 2010. Deoxynivalenol affects in vitro intestinal epithelial cell barrier integrity through inhibition of protein synthesis. Toxicol. Appl. Pharmacol. 245:291-298.

Wu, Q., V. Donhal, L. Huang, K. Kuca, and Z. Yuan. 2010. Metabolic pathways of trichothecenes. Drug Metab. Rev. 42:250-267.

Young, J. C., T. Zhou, H. Yu, H. Zhu, and J. Gong. 2007. Degradation of trichothecene mycotoxins by chicken intestinal microbes. Food Chem. Toxicol. 45:136-143. 